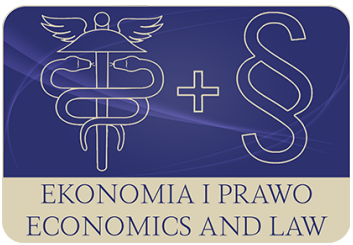

EKONOMIA I PRAWO. ECONOMICS AND LAW

Volume 16, Issue 4, December 2017

p-ISSN 1898-2255, e-ISSN 2392-1625

www.economicsandlaw.pl

ORIGINAL ARTICLE

received 13.06.2017; revised 01.12.2017; accepted 31.12.2017

Citation: Busłowska, A., \& Wiśniewska, B. (2017). The Bialystok Functional Area Competency Center as an example of development of human capital. Ekonomia i Prawo. Ecomomics and Law, 16(4):

371-385. doi:10.12775/EiP.2017.026.

\title{
The Bialystok Functional Area Competency Center as an example of development of human capital
}

\author{
ANNA BUSEOWSKA \\ corresponding author \\ University of Bialystok, Faculty of Economics and Management, Department of Regional Policy \\ and Project Management, ul. Warszawska 63, 15-062 Białystok, Poland \\ ๑a.buslowska@uwb.edu.pl \\ BEATA WIŚNIEWSKA
}

Bialystok School of Economics, Department of Economics, Poland

$\square$ beata.wisniewska@wse.edu.pl

\begin{abstract}
Motivation: Today, the value of skilled, complex and creative work is growing fast. In the global knowledge economy, people's knowledge, skills learning, talents and abilities - their human capital - have become a main factor of economic growth. In many regions, the potential of human capital is restricted, e.g. in podlaskie voivodship. Particular problems exist in the field of vocational education as a result of long-term under-funding of vocational schools, reversal of proportion in choice between vocational and regular high schools, etc. Especially in the field of vocational education exists low quality of training. Education systems can do much to help people realise their potential and external funding (e.g. EU) can support innovative projects for the development of human resources.
\end{abstract}

Aim: The main goal of this article is to show an example of innovative project in the field of vocational education that have an influence on development of human capital. In frame of EU instrument called Integrated Territorial Investments in Bialystok Functional Area

(BFA) is implementing project of BFA Competence Center. The project is to support the development of knowledge, professional skills, talents and abilities.

Results: The analysis led to the following conclusions: vocational education requires a broad integrated support; cooperation with different stakeholders (especially with em- 


\section{ployers, organizations of business environment, etc.) is essential to achieve high-quality education; a vocational education should be more attractive for pupils.}

Keywords: human capital; human development; economic development

JEL: 24 ; 015

\section{Introduction}

Human resources development is one of the sources of companies' competitive advantage. The quality of human resources depends on whether and how an enterprise uses its resources and whether functions effectively in the modern world. It not only influences the economic growth, but increases national competitiveness. Moreover, human capital affects the growth of other kinds of the capital (Vaitkevičius et al., 2015, p. 1641).

One of the elements of building high quality human capital is the educational system. Employees expect the high qualifications necessary to perform specific job functions. Therefore vocational education system is of great importance in this process.

The main goal of this article is to show an example of innovative project in the field of vocational education, that supports human capital development. In frame of EU instrument called Integrated Territorial Investments (ITI) 1 in Bialystok Functional Area (BFA) is implementing project BFA Competency Centre - the comprehensive model of support and modernization of vocational education system in Biatystok Functional Area. The project's aim is to support the development of knowledge, professional skills, talents and abilities of pupils in vocational schools and limit competence gaps in BFA.

\section{Literature review}

In literature, human capital is broadly defined. It is described as intangible resources like: knowledge, skills, intelligence, enterprise's labor force's capabilities. (Baron \& Armstrong, 2012, p. 20; Bontis et al., 1999, pp. 391-402). Some authors have defined human capital as the combination of only four personal factors: genetic inheritance, education, experience, and attitudes toward life and business. Human capital is also understood as capabilities, knowledge, skills, and experience of employees, including the values, culture, and philosophy of the firm. It is also seen as a tacit and explicit knowledge that belongs to the people. Simply, it can be defined that the sum of knowledge of the members within an organization. (Vargas et al., 2016, pp. 961-978). Bontis et al. (1999) also believes that human capital is the collective capability of an organization to develop the best solutions based on individuals' knowledge. In other

1 This instrument is dedicated to solving specific problems of territorial urban centers (functional areas). ITI provides a flexible mechanism for formulating integrated responses to diverse needs formulated within the framework of development strategy (Ministerstwo Rozwoju, 2015, p. 217). 
definitions, it is pointed out that human capital corresponds to employees' capabilities and satisfaction or it is a combination of employees' capabilities, competencies and the way they are managed. (Vargas et al., 2016, pp. 961-978). Davenport emphasized that human capital also includes specific patterns of behavior, personal energy, and innate abilities. Human capital theory shows employees as individuals with specific skill set that can be rented to employers for an appropriate fee (Baron \& Armstrong, 2012, p. 21).

Other definitions of human capital also link to learning and innovation. Bontis (1998, pp. 63-76) underlines that communication and learning process of individuals through their involvement in the production process of the organization is a source of innovation and value for the company. Human capital is defined as factors which create assumptions or possibilities to create innovations or strive for higher productivity.

Some authors also underline that human capital is a critical determinant of economic development. (Čadil et al., 2014, pp. 85-92; Lee \& Lee, 2016, pp. 147-169; Schultz, 2014, pp. 96-101; Shuaibu \& Oladayo, 2016, pp. 523-549). Mincer (1981, pp. 1-30) already in the eighties emphasized that human capital activities involve the production of new knowledge which is the source of innovation and of technical change and generates worldwide economic growth. In particular, studies on the education system were conducted by Lee \& Lee (2016, pp. 147-169). The studies revealed great achievements in educational expansion throughout the world, as well as significant progress in economic development. This increased growth was accompanied by rapid capital accumulation and technological progress. It played an important role in many countries' transitions from low-income, uneducated societies to high-income, well-educated societies and their structural change from rural and agricultural to urban and industrial. Becker (1994, pp. 15-28) emphasizes that 'education and training are the most important investments in human capital'. His research concerned in particular the impact of education on the level of earnings and he indicates that high school and college education in the United States greatly raise a person's income.

To summarize the reflections on understanding human capital it should be pointed out that there is something different then intellectual capital, structural capital or customer capital. First of them is defined as the combination of all intangible elements rooted in knowledge which an organization can leverage to gain a competitive advantage and create value. Structural capital is a structure, procedures, etc. that allow an organization to encode and disseminate knowledge, skills, etc. generated by human capital. Customer capital comprises knowledge about an organization's relationships with other business partners. (Vargas et al., 2016, pp. 961-978)

In our study, we focused on human capital. For the purpose of this article, it was assumed that human capital is a combination of elements such as: knowledge, skills, abilities, creativity and experience, which are the set of rare, valuable, inimitable, and non-substitutable intangible resources. 
The issues of human capital development are increasingly becoming the most important field of scientific research. There are a number of scientific researches representing peculiarities of development of human capital in different countries. However, there is still a gap in research (Vaitkevičius, 2015. pp.1641-1648).

Bialystok Functional Area consists of 10 municipalities: Bialystok, Choroszcz, Czarna Białostocka, Dobrzyniewo Duże, Juchnowiec Kościelny, Łapy, Supraśl, Turośn Kościelna, Wasilków and Zabludów. They occupy an area of approx. 9\% of the Podlasie region. Population is around 411.5 thousand people (over $34 \%$ of the Podlasie region's residents, and $72 \%$ BFA's population is concentrated in Bialystok). The functional area was created in order to implement the new EU instrument which is integrated territorial investments (SBOF, 2016, pp.12-17).

The main document defining general development objectives of BFA is Integrated Territorial Investment Strategy of Biatystok Functional Area for the years 2014-2020 (SBOF, 2016, p.159), which include 7 basic fields of development: investment attractiveness; competence to work; accessibility to culture; active social inclusion; low-carbon economy and environment; communicational accessibility and integration of BFA strategic development management. Analyzing the Strategy, it may be noted that the emphasis in shaping the development of the BFA is put on human capital and professional competence, in particular, the development of vocational education. This is due to diagnosis of problems existing in this field as described below.

In Bialystok Functional Area in 2014, there were 18 teams of vocational schools, most of them in the city of Bialystok. Individual institutions are also in Łapy and Czarna Białostocka. In 2013, vocational and technical schools in the Bialystok Functional Area educated 8538 students in 70 professions. Just ten occupations concentrated nearly half of all vocational school students. Among them were: IT technician (737 students), car technician (550 students), hotel management technician (533 students), mechanic technician (431 students), hairdressing services technician (431 students), construction technician (385 students), nutrition and food services technician (31l students), cook (303 students) and car mechanic (303 students). Unfortunately all these professions are surplus to the regional labor market, because there is a lack of jobs for all graduates of such education. (SBOF, 2016, p. 122)

This is one of the reasons for structural mismatch of supply and demand for labor in the region. The essence of the problem lies in the professional competence structure of the unemployed and is caused mainly by the competence inadequacy to the regional employers' expectations. Within the BFA, the largest deficit was recorded among workers in such occupations as scaffolding fitter, call center worker, telecommunications fitter, carpenter and technician of physical protection of people and property, and the highest surplus professions on the list were: clothing technology technician, economist, small catering chef, electrical technician, or physical education teacher (BFKK, 2014, pp. 24-25). 
At the same time it should be emphasized that the directors of vocational schools do not ignore the problem. The surveys often show that they know that the school offers education in surplus professions, but on the other hand, the employers report the demand for such jobs. The results of Białystok Foundation of Professional Training (BFKK, 2014, pp. 25-27) survey confirm that $100 \%$ of schools are in contact with employers in order to adapt the training offer to their needs. Almost all schools (94\%) analyze data from the Provincial and District Labor Office and uses feedback from graduates. A large percentage of schools (65\%) is based on an intuitive market research and information obtained from research reports. Half of the schools (53\%) uses information from the Board of Education. Knowledge from contacts with employers' organizations is obtained by about $47 \%$ of institutions and contacts with crafts features, chambers of craft declares $24-35 \%$ of schools.

Interestingly, as long as schools fully declare their cooperation with entrepreneurs, the problem of obstructing the adaptation of competence and qualifications of human resources of the BFA, is also low cooperation with schools by employers.

The study, conducted by Białystok Foundation of Professional Training (2014, p. 88), shows a small range of cooperation between employers and school. More than half of the respondents did not see the need and the benefits of cooperation with schools. Over $80 \%$ of employers who employ graduates of vocational schools do not work with these schools in any form. As the main reason for this state, entrepreneurs didn't indicated such a need. At the same time, $32 \%$ of respondents considered that this is due to legal regulations related to the employment of young workers. The problem is also the lack of cooperation standards and employer's support for keeping record related to the practical training organization in accordance with the requirements of the educational system. Almost half (43\%) of entrepreneurs believe that the most significant barrier to cooperation with vocational schools is that there is no time for such activities. On the other hand, $16 \%$ of respondents considered that they have insufficient knowledge in this area, and 15\% do not see the benefits of such activities. On the other hand, $100 \%$ of vocational schools from the BFA organizes trips to factories for students, and more than half (53\%) adjusts the educational offer to the needs of employers. Financial support from employers is used by $47 \%$ of schools.

Another factor which handicaps obtaining high qualifications and practical skills of vocational school students is also the difficulty in accessing high-quality professional internships (chart 1).

Almost $70 \%$ of vocational school students' practices take place in school workshops or in school labs, which do not fully reflect the specifics and working environment in a given profession. Only about $11 \%$ of trainees in vocational schools could be held at the employer's practice. These data show a large gap in the organization of this type of support. 
Analyzing further research of Bialystok Foundation of Professional Training (BFKK, 2014, p.60-63) in Bialystok Functional Area for compliance of positions at which employed graduates work with their learned profession and acquired competencies, it can be seen that only 55\% of them work in their profession.

The main reason for the graduates from the BFA not to perform work in their profession was that they did not find work in this profession (more than $84 \%$ of respondents). At the same time, schools see demand for certain deficit professions, but they do not have educational opportunities due to lack of teaching facilities and properly qualified teaching staff. Analysis of the data for vocational schools' teachers indicates that only a third of all teachers (30\%) had previously worked in their profession. Only $12 \%$ of teachers in vocational schools in the BFA had the opportunity to take advantage of internships in companies in order to improve professional competence. Raising the qualifications via vocational courses was declared by $52 \%$ of surveyed teachers working in vocational schools in the BFA. This indicates that a large part of vocational schools in BFA insufficiently care about teachers' qualifications (chart 2).

Entrepreneurs' evaluation of the main reasons for difficulties in recruiting new staff with appropriate qualifications pointed to: lack of staff with relevant experience (41.7\%), lack of local people willing to work (16.7\%) and that the vocational school graduates do not have the qualifications and skills sought by employers (BFKK, 2014, pp. 25-29).

In addition, the unfavorable situation of vocational schools enhances the overall relatively low level of economic development of the Podlasie region, including the BFA, which affects a limited number of jobs. For this reason, labor resources in the functional area are not fully utilized. Gross Domestic Product per capita in 2014 amounted to 32350 PLN and accounted for approx. 72\% of the national average. In 2015, the number of newly created jobs in Podlasie region was 12 thousand. This was approx. $2 \%$ of the total number of new jobs in the country (Local Data Bank, 2017).

Given the above analysis we can state a lot of problems in the field of vocational education, which affect the quality and usability of human capital in Bialystok Functional Area on the regional labor market. They concern not only the matching of supply and demand for labor, but also the quality of education, often insufficient cooperation between schools and employers, and lack of understanding each other's needs. EU policy puts great emphasis on financing the development of human capital. Significant funds for this purpose (13 939699 EUR) were provided in the ITI Strategy of BFA. Part of this sum was dedicated to BFA Competency Center, which activities and results are described in the next paragraph of the article.

\section{Methods}

The article was based on case study analysis. Firstly, a research, related to importance of human capital and the state of vocational education in BFA was 
made on the basis of literature, strategic papers, research reports and other official statistics, as well as vocational education report prepared by Bialystok Foundation of Professional Training (BFKK). This research was an introduction to the case study of the project BFA Competency Centre, which is implemented within the framework of Regional Operational Program for Podlaskie Voivodship 2014-2020 and Integrated Territorial Investment Strategy of Biatystok Functional Area for the years 2014-2020 (ITI Strategy of BFA). The aim of the research was to check how the activities in the project correspond to the basic problems of vocational education in BFA. The main research questions concerned following issues: what are the main problems of vocational education in BFA; what are the main activities of BFA Competency Center in supporting the development of human capital in BFA and will they be able to complexly influence the development of human capital in vocational schools? The project started in 2017 and will last until 2021, therefore the article presents its main assumptions. The final conclusions regarding the effects will be possible to be made after its completion. Data concerning the case study (project) were analysed and interpreted on the basis of the application form for co-financing of the project of December 5, 2016 and they were provided by BFKK employees (project partner).

\section{Results}

Vocational education and adjusting it to the needs of regional labor market is an indispensable element of building economic development through a constant improvement of human capital quality. Vocational education system must link the problems of the three main stakeholders - students, schools and the surrounding.

The existing system of education is restricted by school resources (equipment and staff) and employers collaborating with schools (technologies). Schools, by focusing on collaboration with the available employers, are not able to foresee future needs. Therefore, the competency gap connected with a lack of adjustment of educational offer to employers' needs starts emerging. It is also the result of little interest of candidates in learning (it results from demographic decline) and little popularity of vocational schools. The third factor influencing the competency gap in BFA is too little supply of adequate competencies caused by low efficiency of labor market instruments (BFKK, 2014, pp. 88-93). Due to the fact that the dual education system is not able to solve the aforementioned problems - the trial to reduce the competency gap in BFA was undertaken by the project BFA Competency Centre - the comprehensive model of support and modernization of vocational education system in Biatystok Functional Area. It is an inter-sector cooperation between the governing bodies of schools and vocational education facilities operating in BFA - the City of Białystok and a non-governmental organization - the Bialystok Foundation of Professional Training. The value of the undertaking amounts to over $16.0 \mathrm{mln}$ PLN, including the EU funding - $15.2 \mathrm{mln}$ PLN. The aim of the project is to improve the BFA's inhab- 
itants competencies so that they constantly suit the current needs of the existing and emerging work places, which would result in the increase in employment and remuneration of the functional area's inhabitants. The center combines the supply and demand aspects of the labor market and takes equal care of all the education system stakeholders. It constantly acts to match the competencies of students or people taking educational and professional decisions (to the needs of regional economy. The objective of the undertaking, apart from creating the real platform for cooperation between employers, educational facilities and the labor market, especially vocational schools, is the creation of demand career counseling based on the needs of employers as well as the improvement in vocational education systems in the context of the systematically diagnosed competency gap in terms of measurable and standardized competencies to work. Moreover, the competency needs of employers will be satisfied, which will influence the economic and social development of BFA. The BFA Competency Centre model predicts eight complementary activities dedicated to the particular aspects of the competency gap that will support the activities of schools and vocational education facilities (scheme 1). This various tasks have been characterized below.

Modernization of vocational education system is in this sense mainly an adjustment of educational offer to the dual needs of employers and inhabitants (often distinct as a result of failed or unreal educational ambitions), and thus it is the solution guaranteeing vocational training efficiency on one hand and its popularity and openness to inhabitants' needs and proper inflow of candidates for vocational education, on the other. The Competency Centre model manages the process of reducing the competency gap by taking into account five levels of its identification: occupations, qualifications, skills, activities and professionalism. The competency needs of companies will be examined every year - in 5 editions - on the trial group of 120 enterprises and 360 employees in BFA. Furthermore, the examination of educational needs and ambitions of BFA inhabitants pertaining to objective professional predispositions and educational possibilities shall be conducted with the same frequency and number and cover the trial group of 500 people and 50 educational facilities. Every year, annual recommendations shall be prepared in the field of new specializations, apprenticeship programmes and traineeships, etc.

The objective of action Development programmes is to support 15 vocational schools from BFA in preparing development programmes and in the process of elaborating new educational programmes. These programmes have to respond to new competency needs of employers as well as forecasted educational needs and ambitions of inhabitants. The activity includes also an additional modernization aspect - in relation to employers and potential students of the school i.e. endogenous internal developmental needs of the educational facility. The complementary development programmes of schools are to include three levels of modernization: student, school as well as the surrounding and they should indicate three model areas i.e. practical education, career and e-educa- 
tion field. Within the activity, there will be seminars, workshops and trainings for modernizers - 39 teachers engaged in preparation and implementation of the development programme as well as modernization coaching and schools' evaluation during the implementation of development programmes.

Next task of the project aims to improve employability of students from schools and vocational as well as general education facilities by elaborating and implementing in practice new solutions in the field of the competency gap supplementation. After consultations with employers and teachers of the profession, the catalogue of supplementary courses (specialist trainings, qualification vocational courses and professional skills courses) will be developed as well as the rules for their organization. Moreover, additional specialist classes will be realized for students enabling them to gain and supplement knowledge and professional qualifications in order to match them properly to real needs of regional and local labor markets. The programmes of courses and apprenticeships are to be designed in the way as to help gain competencies within one of 243 occupation activities and to pass the exam according to developed standards. Courses offer will be complemented with courses related to key, social and soft competencies. The result of the Activity's implementation will be 600 monthly apprenticeships in enterprises for BFA students, specialist trainings, professional qualifications courses, professional skills courses for 1000 students.

The next detailed objective of the project is the creation of professional skills validation and certification system, with the participation of employers, which would complement the present system of confirming professional qualifications carried out by the Regional Examination Boards. The developed system will enable 600 students to confirm partial qualifications they possess, i.e. proving them on the level of professional skills or activities.

Competency counseling implemented within next action aims to prepare in BFA innovative, in the scale of Poland, system of BFA demand counseling integrated with the process of diagnosing and describing the BFA's competency gap as well as with the process of competency validation and certification. It will be based on developing job predispositions in tasks and conditions similar to the selected professional environment by the Assessment Center method (recruitment method based on assessing numerous competencies and conditions of employer's functioning through tasks especially designed to examine employees' suitability for the particular post (Bray, 2002, pp. 245-247)). According to the BFA Competency Centre, the evaluation shall be made by practical trial method in the field of professional competencies with the use of diagnostic boxes, under the supervision of a Competency Counselor, in the form of exercises assessing activities characteristic to particular professions and industries. Within the project, the methodologists of vocational education and professional counselors specializing in diagnosing professional predispositions will prepare the pilot package of tools and scenarios of exercises for 80 typical activities (the source of assessment) for 8 fields of education (industries) in professions: service and administration, construction, electric and electronic, 
medical and social and artistic. Additionally, there will be 20 boxes prepared to measure general and universal competencies within the cognitive, manual and operational predispositions. Within the planned educational counseling, 3000 students will be granted support in the field of improving professional competencies, in the form of the Individual Action Plan for Competencies - every participant will receive information on an individual competency gap as well as the proposal of supplementary trainings and apprenticeships.

Within sixth project action, modern educational resources shall be elaborated. The prepared modern, interactive and multimedia educational packages for learning a profession will constitute the key instrument for popularizing vocational education and providing positive support for professional and educational choices of the youth. They will be made available to all schools and vocational education facilities in BFA in order to modernize the currently taught specializations and prepare new educational offer and thus provide the comparative standard and quality of education in all development programmes realized in BFA. In order to ensure durability and accessibility of elaborated materials, they will be shared on the Podlaskie Educational Platform. Each package shall contain instructions on carrying out the TIK solutions in programme's implementation. The organizers of educational forms shall be provided with methodological and technical support in the field of e-education.

The aim of next action is to improve vocational education quality in cooperation with employers. Within the project, the accreditation system will be created that will help grand certificates of high level of education in particular professions. This system will be based on the general verification concept of higher education quality with the adjustment to vocational education. The system of accreditation will employ external experts, especially employers.

The implementation of previous undertakings will be complemented by the cooperation between schools and vocational education facilities with universities. This cooperation aims to provide students with the accessibility to current state of knowledge, motivate them to learn and simultaneously increase professional competencies of teachers of particular professions. Within this project action, there will be classes preparing to commence studies, didactic classes in laboratories/ university premises, telelectures provided by academic teachers, seminars popularizing education directed to students as well as research and implementation projects of students' scientific circles with the participation of vocational schools' students.

Bearing in mind the special role of vocational education in BFA economy as well as possibilities of supporting its development with the use of European funds within the Regional Operational Programme for Podlaskie Voivodeship 20142020 within the Integrated Territorial Investment Strategy of Biatystok Functional Area for the years 2014-2020 the project BFA Competency Centre is implemented as one of the elements of innovative systemic approach to vocational education development (scheme 2). 
Vocational education facilities in BFA are complementarily supported from the funds of the European Social Fund in implementation of comprehensive development programmes as well as of the European Regional Development Fund in the field of indispensible infrastructure's development. Additionally, the BFA Association is engaged in the implementation of the undertaking pertaining to vocational education popularization.

The model system of support for vocational schools in the field of preparing and implementing development programmes, including the preparation of new educational programmes, is implemented by the BFA Competency Centre and is the key instrument of modernizing vocational education system from the point of view of development human capital.

\section{Conclusion}

Human capital quality decides on economic development and competitive advantage of regions. It is important to adapt it to the needs of entrepreneurs. Proper vocational education, adjusted to current and future labor market needs, is a crucial element of every education system (CEDEFOP, 2011). Vocational education not only provides the labor market with properly prepared human resources, but also builds entrepreneurial potential among students, who after finishing education set up their own economic activity and, what is also important, awakens the need of lifelong learning. In knowledge-based economy, the support of its development should be one of the most important elements of regional policy. The BFA Competency Centre is a holistic model of support and modernization of the vocational education system in the BFA. The project is innovative in a regional scale. Planned actions in the project were not implemented before in the region in such a comprehensive and complementary manner.

All the activities directed to vocational education entities have a common objective i.e. increasing the employability of school and vocational education facilities students or the improvement of technical base. In case of vocational education, systemic approach, which joins all or almost all stakeholders, helps create the model of mutual relationships and impacts among all of them and among the socio-economic environment. The result of undertaken activities should be the connection of vocational education with industrial sector and economic activity spheres for continuous adjustment of specializations to human resource needs of the labor market.

In this context, the especially valuable examples are the activities undertaken in Białystok Functional Area - implementation of the BFA Competency Centre project as well as complementary activities described in the article, as they include the comprehensive approach to vocational education and the fact that essential changes in this field demand strict collaboration between administration, education and employers. 


\section{References}

Baron, A., \& Armstrong, M. (2012). Zarządzanie kapitatem ludzkim. Uzyskiwanie wartości dodanej dzięki ludziom. Warszawa: Wolters Kluwer Business.

Becker, G.S. (1994). Human capital revisited. In. G.S. Becker (Ed.), Human capital: a theoretical and empirical analysis with special reference to education (3rd Edition). Chicago: Chicago: University of Chicago Press.

BFKK. (2014). Kształcenie zawodowe na terenie Biatostockiego Obszaru Funkcjonalnego. Raport wykonany na zlecenie Stowarzyszenia Biatostockiego Obszaru Funkcjonalnego. Retrieved 23.03.2017 from, http://www.bof.org.pl.

Bontis, N. (1998). Intellectual capital: an exploratory study that develops measures models. Management Decision, 36(2). doi: 10.1108/00251749810204142.

Bontis, N., Dragonetti, N.C., Jacobsen, K., \& Roos, G. (1999). The knowledge toolbox: a review of the tools available to measure and manage intangible resources. European Management Journal, 17(4). doi:10.1016/ S0263-2373(99)00019-5.

Bray, D.W. (2002). Centered on assessment. Retrieved 19.03.2017 form http:// www.assessmentcenters.org.

Čadil, J., Petkovová, L., \& Blatná, D. (2014). Human capital, economic structure and growth. Procedia Economics and Finance, 12. doi:10.1016/ s2212-5671(14)00323-2.

CEDEFOP. (2011). Medium-term priorities 2012-14. Retrieved 19.03.2017 form http://www.cedefop.europa.eu.

Lee, J.W, \& Lee, H. (2016). Human capital in the long run. Journal of Development Economics, 122. doi:10.1016/j.jdeveco.2016.05.006.

Local Data Bank. (2017). Retrieved 23.03.2017 from https://bdl.stat.gov.pl.

Mincer, J. (1981). Human capital and economic growth. NBER Working Paper, $1 / 803$.

Ministerstwo Rozwoju. (2015). Programowanie perspektywy finansowej 20142020. Umowa Partnerstwa. Retrieved 19.03.2017 from https://www.funduszeeuropejskie.gov.pl.

SBOF. (2016). Strategia Zintegrowanych Inwestycji Terytorialnych Biatostockiego Obszaru Funkcjonalnego na lata 2014-2020. Retrieved 19.03.2017 from http://bof.org.pl.

Schultz, T.W. (2014). Ekonomia kapitatu ludzkiego. Warszawa: Wolter Kluwer Business.

Shuaibu, M., \& Oladayo, P.Z. (2016). Determinants of human capital development in Africa: a panel data analysis. Oeconomia Copernicana, 7(4). doi:10.12775/OeC.2016.030.

Vaitkevičius, S., Čiutienè, R., Meilienè, E., \& Savanevičienè, A. (2015). Typology of human capital development in EU countries. Procedia Economics and Finance, 23(2015). doi:10.1016/s2212-5671(15)00520-1. 
Vargas, N., Lloria, M.B., \& Roig-Dobón, S. (2016). Main drivers of human capital, learning and performance. Journal of Technology Transfer, 41(5). doi:10.1007/s10961-016-9483-6.

\section{Acknowledgements}

Author contributions: authors have given an approval to the final version of the article. Authors contributed to this work equally.

Funding: this research was fully funded by the University of Bialystok, Faculty of Economics and Management, Department of Regional Policy and Project Management and Bialystok School of Economics, Department of Economics statutory sources.

Note: the results of this study were presented at 9th International Conference on Applied Economics Contemporary issues in Economy (June 22-23, Torun, Poland). 


\section{Appendix}

\section{Scheme 1 .}

\section{Support model within the BFA Competency Centre}

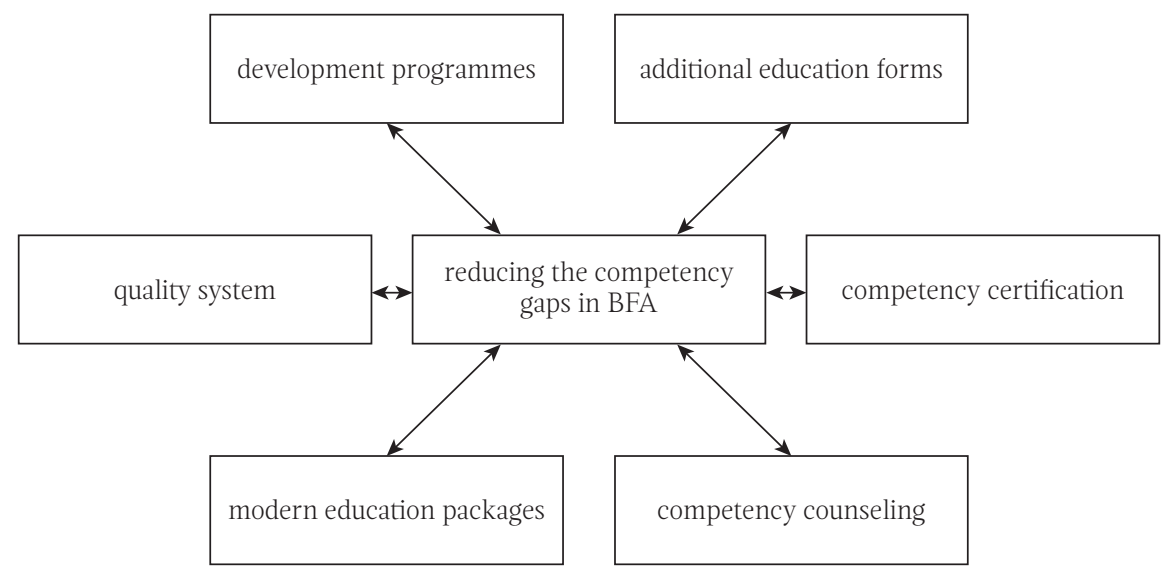

Source: Own preparation based on the application form for co-financing of the project BFA Competency Centre - the comprehensive model of support and modernization of vocational education system in Biatystok Functional Area.

\section{Scheme 2.}

Support model within the BFA Competency Centre

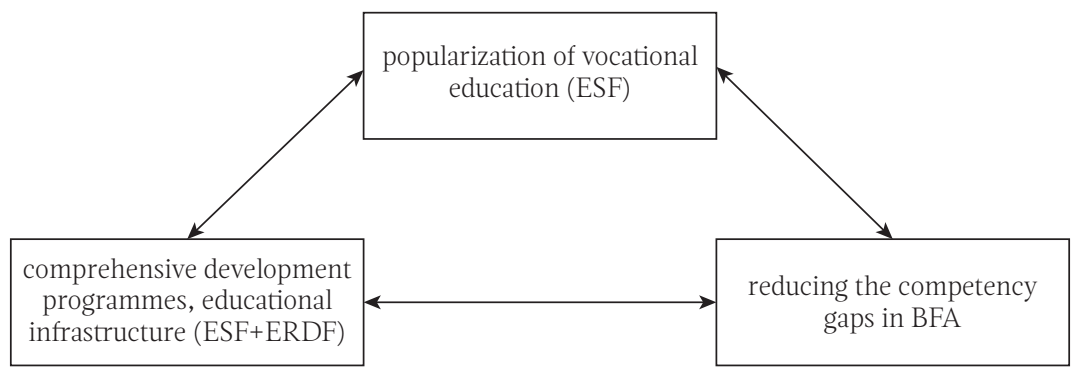

Source: Own preparation based on the application form for co-financing of the project BFA Competency Centre - the comprehensive model of support and modernization of vocational education system in Biatystok Functional Area. 


\section{Chart 1.}

Place of apprenticeship for vocational school students

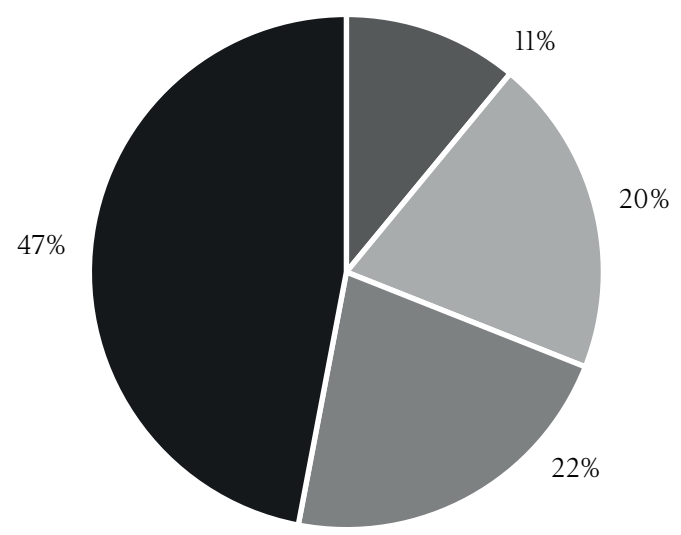

- employers - school workshop - practical training centre - school lab

Source: Own preparation based on SBOF (2016, p. 116).

\section{Chart 2.}

Reasons to work in a profession other than the learned

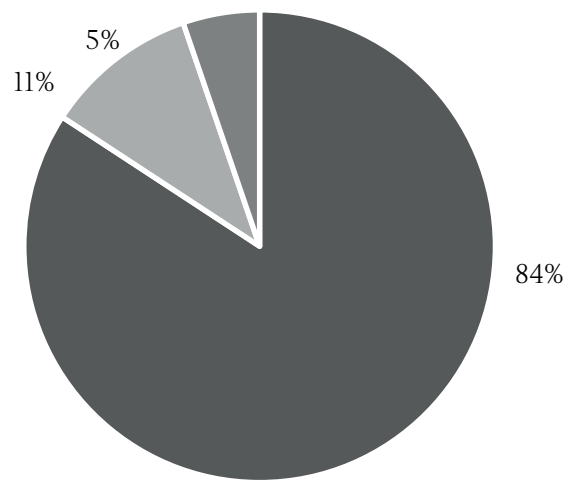

- I didn't find a job in my profession

- I had an opportunity for an appealing job in a different area

- I changed my interests

Source: Own preparation based on BFKK (2014, p. 62). 
